\title{
Use of Soil-Structured Capillary Barrier can Mitigate the Impact of Saline-Irrigation Water on Marigold Grown Under Field Condition
}

Mohammed S. Al-Mazroui ${ }^{1 *}$, Rashid A. Al-Yahyai ${ }^{1 *}$, Said S. Al-Ismaily², Anvar R. Kacimov ${ }^{2}$, Hamed Al-Busaidi ${ }^{2}$

$$
\begin{aligned}
& \text { استخدام الحاجز الشعري المركب للتربة للحد من تأثير مياه الري المالحة على } \\
& \text { نبات الماريجولد المزروعة تحت الظروف الحقلية }
\end{aligned}
$$

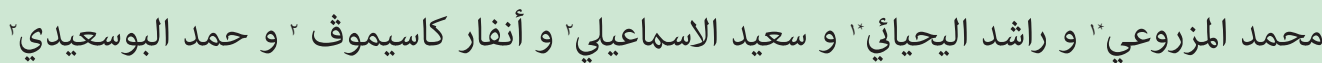

ABSTRACT. Capillary barriers (CBs) as engineered porous composites is novel and promising technology for mitigating salinity and drought stress of plants. This study aimed to imitate a naturally formed CB structure recently discovered in the reservoir bed of Al-Khoud dam at the Governorate of Muscat in northern Oman and to test the impact of this unique $\mathrm{CB}$ on mitigating the salinity stress of marigold plants grown under an open field condition. A plot was constructed and divided into "structured" (engineered cascade CB design) and "unstructured" soils and planted with marigold (Tagetes erecta) plants that were subjected to four salinity treatments (control with $\mathrm{EC}_{\mathrm{i}} \approx 0.6 \mathrm{dS} \mathrm{m} \mathrm{m}^{-1} ; 3 \mathrm{dS} \mathrm{m}^{-1}$; $6 \mathrm{dS} \mathrm{m}^{-1}$; and $9 \mathrm{dS} \mathrm{m}^{-1}$ ). Plant physiological, vegetative, and reproductive growth parameters were measured in each treatment. The results showed that the structured soil significantly saved irrigation water and reduce salts accumulation. Structured soil improved all vegetative and reproductive plant parameters measured and helped in reducing the effects of salinity stress on the growth and production of the marigold under arid-climate field conditions. The results also showed the capability of structured soil in water saving and improving water use efficiency. This study substantiates a novel method in mitigating salinity problem and in water saving in arid and semi-arid regions, in particular in Oman. Further studies are required to test the use of the engineered cascade CB design with different crops and with alternative (e.g. subsurface) irrigation methods.

KEYWORDS: Soil; Capillary barrier; Structured soil; Soil moisture; Salinity; Plant growth; Arid-climate.

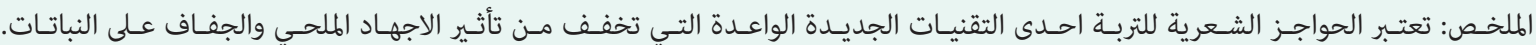

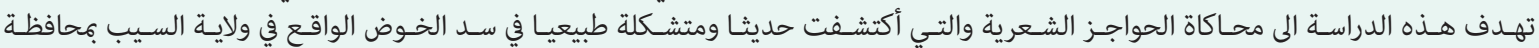

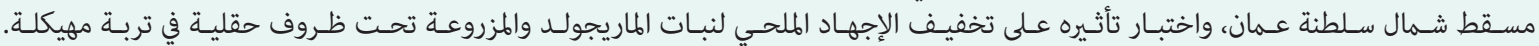

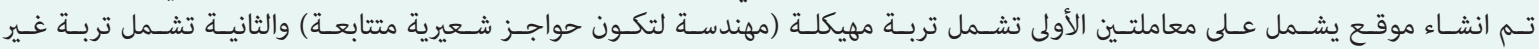

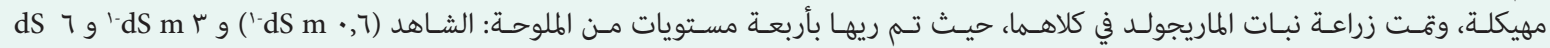

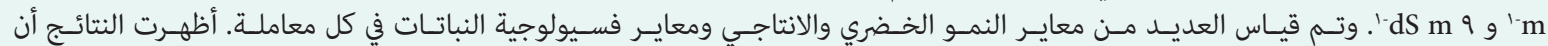

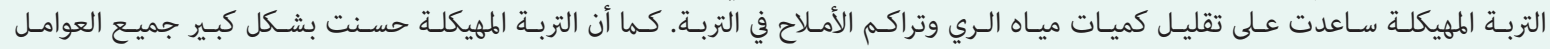

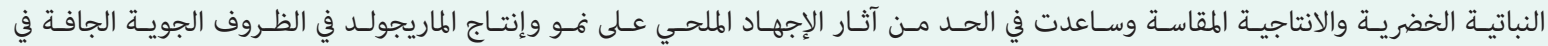

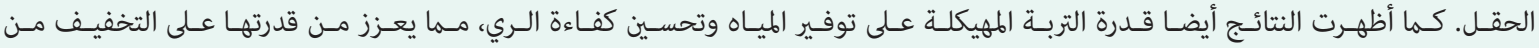

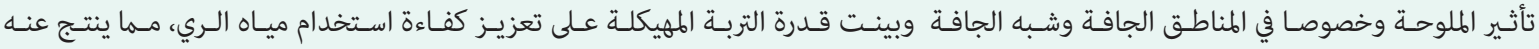

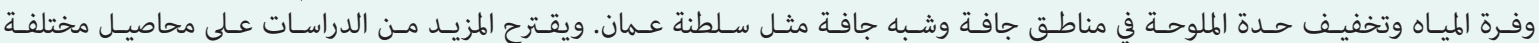

$$
\text { وطرق، ري مختلفـة، لمعرفة مـدى، تأثير، التزبـة، المهيكلة عليهـا. }
$$

\section{Introduction}

S alinity is a major abiotic factor limiting agricultural production in the world and particularly in arid and semi-arid regions. Soil salinity has affected about 952 million hectares (7\%) of land around the world (Al-Mulla, 2010). It is estimated that globally $20 \%$ of total the cultivated area and $33 \%$ of the irrigated agricultural lands are affected by high salinity. Also, more than $50 \%$ of the arable land would be saline by 2050 (Jamil et al., 2011). Ghassemi et al. (1995) estimated that

Mohammed S. Al-Mazroui ${ }^{1 *}(D$ ) mohammed3039@hotmail.com 1 Department of Crop Sciences, Sultan Qaboos University, PO Box 34, Al Khoud 123, Sultanate of Oman . ${ }^{2}$ Department of Soils, Water and Agricultural Engineering, Sultan Qaboos University, PO Box 34, Al Khoud 123, Sultanate of Oman. the annual loss of income from the salinization of irrigated lands is about US\$ 12 billion worldwide.

Soil salinity in Oman is considered a serious threat to the sustainable use of two of the most important natural resources in the country, which are soil and water. The estimated values for salt-affected lands in Oman are approximately $44 \%$ of the total geographical area and $70 \%$ of the arable agriculturally suitable land (Al-Rawahy et al., 2010).

Salinity stress induces several biochemical and physiological changes in plants (Nemoto and Sasakuma, 2002). It can cause osmotic effect, ion toxicity, nutritional imbalance leading to a reduction in photosynthetic efficiency and other physiological disorders. The major inhibitory effects of salinity are quantified via plant 
growth and yield descriptors (Ashraf et al., 1991; Khan et al., 1995). Under high salinity levels, crop growth, leaf surface expansion, and primary carbon metabolism are negatively affected due to osmotic effects, water deficit, nutritional imbalance, and oxidative stress (Kim et al., 2008).

Marigold (Tagetes erecta L.) is an herbaceous annual plant belonging to the family Asteraceae. Marigold is used for ornamental and medicinal purposes. It is also used in cosmetic and perfume industry due to its aromatic nature and essential oil contents (Regaswamy and Koilpillai, 2014). In Oman, Marigold is a major seasonal flowering plant grown in the public parks, gardens, and roadside throughout the year. Marigold is known to grow well under saline conditions (Escalona et al., 2012). However, salinity can affect negatively on the growth and production of marigolds. Sayyed et al. (2014) found that dry biomass, chlorophyll A, chlorophyll B and carotenoids content are reduced under high salinity (150, and $200 \mathrm{mM} \mathrm{NaCl}$ ) of the irrigation water. An increase of more than $100 \mathrm{mM}$ in salt concentrations significantly reduced the shoot fresh weight (Koksal et al., 2016). Salinity of $100 \mathrm{mM} \mathrm{NaCl}$ decreased marigold flower weight, plant fresh and dry biomass, plant height and had a negative effect on physiological processes such as stomatal closure and chlorophylls content decrease (Chrysargyris et al., 2018).

Several techniques are implemented to mitigate adverse effect of salinity on plants such as increasing organic matter in soil, selecting salt-tolerant crops, using irrigation system with uniform water application, high efficiency of irrigation (e.g. drip irrigation and mini-sprinklers) and frequent irrigation with lower doses of water, among others. These techniques aim to lower the levels of salinity in the plant root zone and to improve drainage and to enhance salts leaching (Abrol et al., 1988; Machado and Serralheiro, 2017; Qadir et al., 2000).

Capillary barrier (CB) is one of the engineering techniques used to maximize crop production by improving soil moisture conditions in the root zone. A traditional $\mathrm{CB}$ is a composition of two soil layers having distinct differences in texture and, therefore, hydraulic characteristics. The classical way of creating soil CB is by adding a mulch layer. Recently, there is an increase in CBs studies, especially, by researchers of arid zone soils (Kacimov et al., 2017). A recent novel design of the $C B$ soil substrate involves 3-D structures of soil composites of coarse and fine zones with variable vertical and lateral hydraulic properties (Al-Ismaily et al., 2013; Al-Maktoumi et al., 2014). This CB soil structure optimizes the root zone conditions for cultivating crops under harsh climatic environment such as high temperature (Kacimov et al., 2017), drought (Al-Ismaily et al., 2013; Al-Maktoumi et al., 2014), salinity and poor quality irrigation water (Ityel et al., 2012). In arid and semiarid countries like Oman, the use of $C B$ can be beneficial because it minimizes fresh (irrigation and rainfall) water percolation to deep saline aquifers and evaporation losses. As a result, plant roots get properly aerated by the abundance of air provided in the coarse zones of CBs.

A naturally formed $C B$ structure was discovered in the reservoir bed of the Al-Khoud dam at the Governorate of Muscat in northern Oman (Al-Ismaily et al., 2013). This CB consists of fine (silt) blocks (which can be geometrically approximated as rectangular parallelepipeds) and cracks between these blocks filled with a coarse "proppant" sand. Having this uniquely structured CB allowed the soil to capture a large quantity of water during a relatively short ponding period (less than 1 month) and to conserve this water for long time (over six months) in the cascade of silty blocks at a depth of 0.5 to $2.5 \mathrm{~m}$, despite the high topsoil temperature and lack of rainfall during most part of the year (Al-Ismaily et al., 2013; Al-Maktoumi et al., 2014), resulting in lush wild vegetation emerging in several areas of the reservoir bed.

Normally, salts move with water, for example, during water evaporation, salts get advected by ascending moisture fluxed and accumulate in the top of the soil profile. During infiltration events, these accumulated salts are leached downward. When the soil has layers of contrasting texture (a discontinuity of the soil properties across the interfaces), the vertical fluxes of moisture and solutes become more intricate as compared with homogeneous soils. It has been found that 3-D structured soils conserve water and reduce water evaporation even more than unstructured (homogeneous) soils (Al-Maktoumi et al., 2014). Thus, the CB structured soils conserve water through reducing the evaporation rate, our hypothesis is that the structured soil will be able to minimize salt accumulation in the plants' root zone. In this study, we have investigated the influence of $C B$ structured soils on mitigating salinity stress of marigold grown under field conditions of an arid climate of Oman.

\section{Materials and Methods}

\section{Site Preparation}

The experiment was conducted in an open field at the Agricultural Experiment Station (AES) $\left(23^{\circ} 37^{\prime} \mathrm{N}\right.$, $58^{\circ} 10^{\prime} \mathrm{E}$ ), Sultan Qaboos University (SQU), Al-Khoud, Seeb, Muscat, Oman. An experimental plot made of a concrete block raised bed was constructed. The plot had a total area of $23 \mathrm{~m} \times 8.5 \mathrm{~m}$ and a boundary wall of $80 \mathrm{~cm}$ height. Half of the plot $(11.5 \mathrm{~m} \times 8.5 \mathrm{~m})$ was filled with a homogeneous fine-textured soil (silty loam) brought from the reservoir of Al-Khoud dam. The remaining half of the plot was engineered to resemble the $C B$ structure discovered by Al-Ismaily et al., (2013). Aluminum frame templates, having the size of $175 \mathrm{~cm}$ in length, $45 \mathrm{~cm}$ in width, and $30 \mathrm{~cm}$ height, were designed and manufactured to create the $C B$ structure (Figure 1); where 


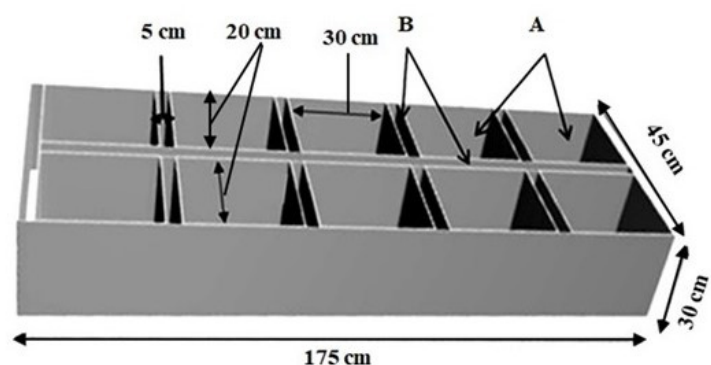

Figure 1. Illustration of the templates used for filling the structured soil

the (A) spaces were filled with a fine-textured soil and the fractures of a small aperture (B) were filled with a sand (coarse-textured soil, also collected from the wadi which feeds the Al-Khod dam; the same sand was found in the natural prototype of the 3-D CB structure of the reservoir (Al-Ismaily et al., 2013). The elementary cell of the periodic 3-D structure in Figure 1 geometrically and hydraulically replicates the parallelepipeds of blocks and "proppant" sheaths in Al-Ismaily et al. (2013) and Al-Maktoumi et al. (2014). Figure 2 represents a side view of the experimental plot showing the structured or CB plot as compared to the unstructured or homogenous plot.

The structured and unstructured plots were prepared and filled with soil in the following manner: for the 'unstructured soil' plot, the area was filled with a fine-textured soil (silty loam) up to $60 \mathrm{~cm}$ in height (Figure 2). The other half of the plot was designated as a'structured soil' plot, and it consisted of two layers (top and bottom) having fine soil surrounded by the sandy fingers (Figure 2). Filling of the structured soil area was as following; (1) a thin layer $(\approx 5 \mathrm{~cm})$ of sand was placed at the bottom of the plot area; (2) aluminum frame templates were used to fill the first (bottom) structured layer at about $30 \mathrm{~cm}$; (3) another thin layer $(5 \mathrm{~cm})$ of sand was placed over the bottom structured layer; and (4) the top layer was filled in the same way using the same aluminum frame templates. The top structured layer was placed in a way it overlapped with the bottom structured layer as shown below in Figure 2. The frames in the top structured layer were filled up to $20 \mathrm{~cm}$ in height, i.e. the top layer is "thinner" than the bottom layer (Figure 2). When the top structured layer was completed, a thin layer $(2 \mathrm{~cm})$ of mulch made of sand was placed over it. The total height of the engineered structured soil was about $60 \mathrm{~cm}$, i.e. same as the height of the unstructured soil in the other half of the plot.

\section{Soil Properties}

Soil texture was determined by using the hydrometer method (Bouyoucos, 1962). The percentages of sand, silt,

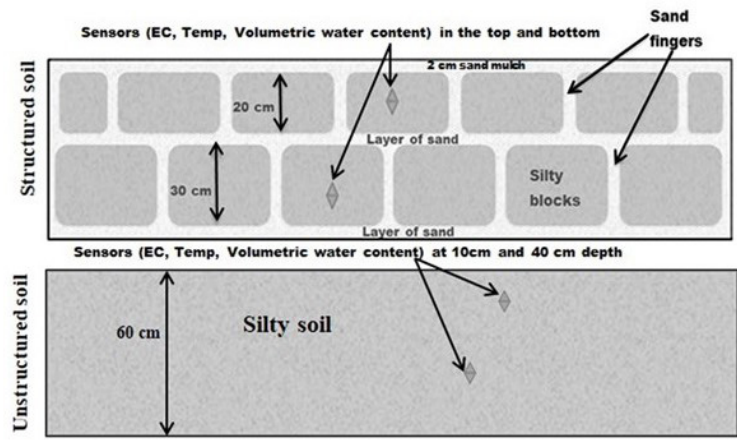

Figure 2. Side view (a vertical cross-section) of the structured soil (top panel) and unstructured soil (bottom panel).

and clay of the soil used for the unstructured soil and in the blocks of the structured soil were $22 \%, 53 \%$, and $26 \%$; the soil texture was silty loam. The soil water retention curve (Figure 3) was determined using the pressure plate apparatus from four suction values (1, 3, 5, and 15 bar) and corresponding volumetric moisture content. These values were plotted in RETC software (Van Genuchten et al., 1991) and the retention curve was constructed using parametric models of Brooks-Corey and van Genuchten. The soil retention curve shows that the saturation point was about $0.42 \mathrm{~cm}^{3} \mathrm{~cm}^{-3}$, field capacity was around $0.32 \mathrm{~cm}^{3} \mathrm{~cm}^{-3}$, and the permanent wilting point of -15 bars was about $0.11 \mathrm{~cm}^{3} \mathrm{~cm}^{-3}$. The measured soil salinity (ECe) and $\mathrm{pH}$ were $1.4 \mathrm{dS} \mathrm{m}^{-1}$ and 8.4, respectively (Rhoades, 1996; Soil Survey Staff, 2014).

\section{Treatments}

Marigold (Tagetes erecta) 'Taishan orange' was used as a model plant in this study due to its extensive use as ornamental and medicinal plant in arid climates and re-

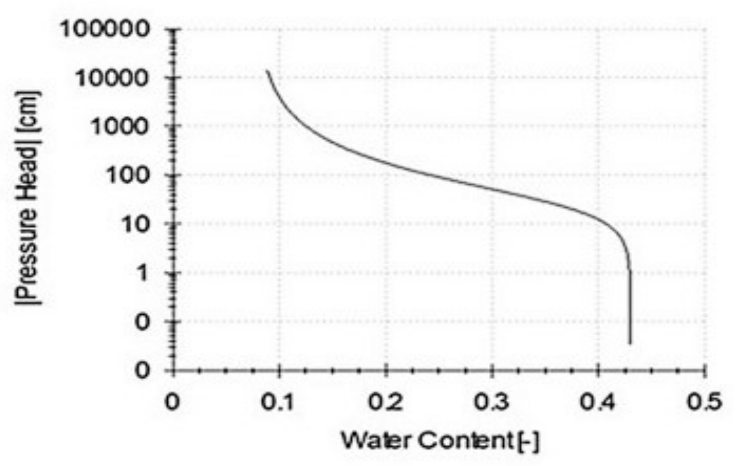

Figure 3. Soil water retention curve of soil used in unstructured area and blocks of structured area predicted by RETC software (water conent: $\mathrm{cm}^{3} \mathrm{~cm}^{-3}$ ) 
A

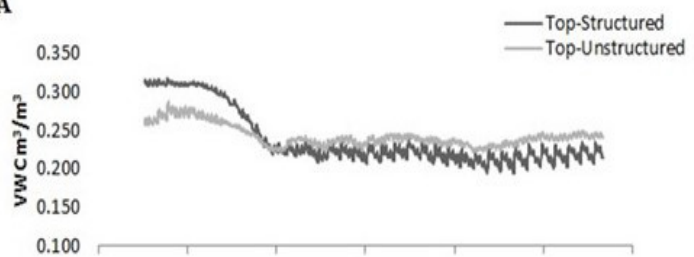

B

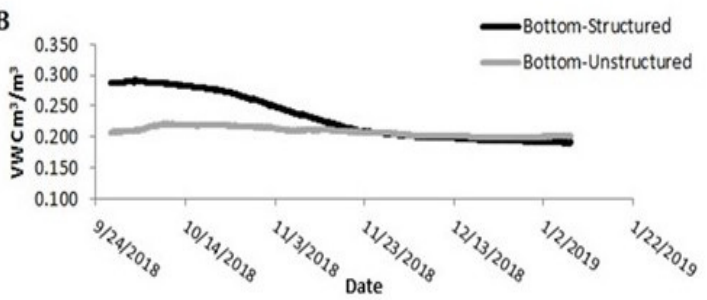

Figure 4. Time series of $\theta v$ in the top (A) and bottom (B) layers of the structured soil and unstructured soil

sponded well to $C B$ studies under controlled conditions (Al-Mazroui et al., 2019) Three-weeks-old marigold seedlings were transplanted and grown in both structured and unstructured soil areas. Initially, all plants in the two areas were irrigated with freshwater (Desalinated, $\mathrm{ECW} \approx 0.6 \mathrm{dS} \mathrm{m}^{-1}$ ) for three weeks. Then, plants were subjected to three salinity levels of irrigation water $\left(\mathrm{ECi}=3 \mathrm{dS} \mathrm{m} \mathrm{m}^{-1}, 6 \mathrm{dS} \mathrm{m}^{-1}\right.$, and $\left.9 \mathrm{dS} \mathrm{m}^{-1}\right)$, in addition to the control (Desalinated water, $\mathrm{ECi} \approx 0.6 \mathrm{dS} \mathrm{m}^{-1}$ ). The irrigation system consisted of three saline stock solutions of $E C=100 \mathrm{dS} \mathrm{m}^{-1}$ and three dosatron injectors (non-electric proportional liquid dispenser) (D3; Dosatron International, Bordeaux, France). The injectors were used to pump $1 \mathrm{M}\left(100 \mathrm{dS} \mathrm{m}^{-1}\right) \mathrm{NaCl}$ salt solution to the freshwater $\left(\mathrm{ECW}=0.6 \mathrm{dS} \mathrm{m}^{-1}\right)$. The injectors were set to inject the salt solution into the freshwater in ratios

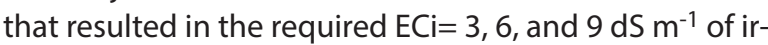
rigation water. Sixty seedlings of marigold were planted in each treatment divided into three lines (20 seedlings in each line). A total of 480 seedlings were planted in the two sections, 240 seedlings for each of the structured and unstructured soils. The inter-plant distance was 50 $\mathrm{cm}$, and the inter-row distance was $50 \mathrm{~cm}$ whereas the boundary between the treatment plots was $1 \mathrm{~m}$.

\section{Irrigation and Fertilization}

Inbuilt drip irrigation system (pressure-compensating drip emitters with flow rates of $4 \mathrm{~L} \mathrm{~h}^{-1}$ ) was installed and used to irrigate the plants. Each treatment had a solenoid valve (electrical valve) connected with an irrigation controller (Hunter's controller). The irrigation controller was programmed to irrigate each treatment separately. The amount of irrigation water given to the plants was based on the field capacity. They were irrigated with approximately $50 \%$ depletion of available water capacity (AWC). All plants were fertilized with NPK (20:20:20+TE) initially through the irrigation system by dissolving $4 \mathrm{~kg} \mathrm{NPK}$ in $4000 \mathrm{~L}$ of desalinated water in the tank. After that, the plants were fertilized through spraying method every two weeks.

\section{Soil Moisture Content and Electrical Conduc- tivity Measurements}

Sensors (5TE, Decagon device, Pullman, WA, USA) were placed at two depth levels to measure soil moisture content $(\theta v)$ and EC (Figure 2). In the structured soil, six sensors were placed in each treatment (3 sensors at the bottom structured layers and 3 sensors at the top structured layers). Thus, a total of 24 sensors were placed in the structured soil area. In the unstructured soil area, also 24 sensors were used. Six sensors were placed for each treatment. Three sensors were placed at $40 \mathrm{~cm}$ depth (the same depth of the bottom layer in the structured soil), and three sensors were placed at 10 $\mathrm{cm}$ depth (the same depth of the top layer in the structured soil). The total number of sensors in the whole plot were 48 . Sensors were connected with data loggers and programmed to read the moisture content and EC every hour. At the end of the experiment, the ECe of the two layers in the structured soil area and the corresponding soil depth $(10 \mathrm{~cm}$ and $40 \mathrm{~cm})$ in unstructured soil were measured using electrical conductivity meter (Oakton waterproof/pcstestr $35 \mathrm{pH} /$ conductivity/TDS/salinity Tester, Oakton, USA).

\section{Plant Growth and Production Measurements}

Vegetative, reproductive and physiological measurements included: shoot height, shoot width (canopy), number and size of flowers, leaf area, fresh and dry weight of shoots and roots, chlorophyll content and chlorophyll fluorescence. Chlorophyll content was measured using Chlorophyll Meter SPAD 502 (Minolta, Japan) whereas chlorophyll fluorescence was measured using Fluor Pen FP100 (Photon Systems Instruments, Brno, Czech Republic).

\section{Water Use Efficiency (WUE)}

We define WUE as the ratio of the yield of a crop $(Y)$ to the total amount of water used in the field per day. WUE of each treatment was computed using the following formula (Sinclair et al., 1984):

WUE $=Y / W R$

where, WUE = Water use efficiency $(\mathrm{g} / \mathrm{L}), \mathrm{Y}=$ vegetative or reproductive biomass (g), WR = amount of water applied for a plant per day (L). 

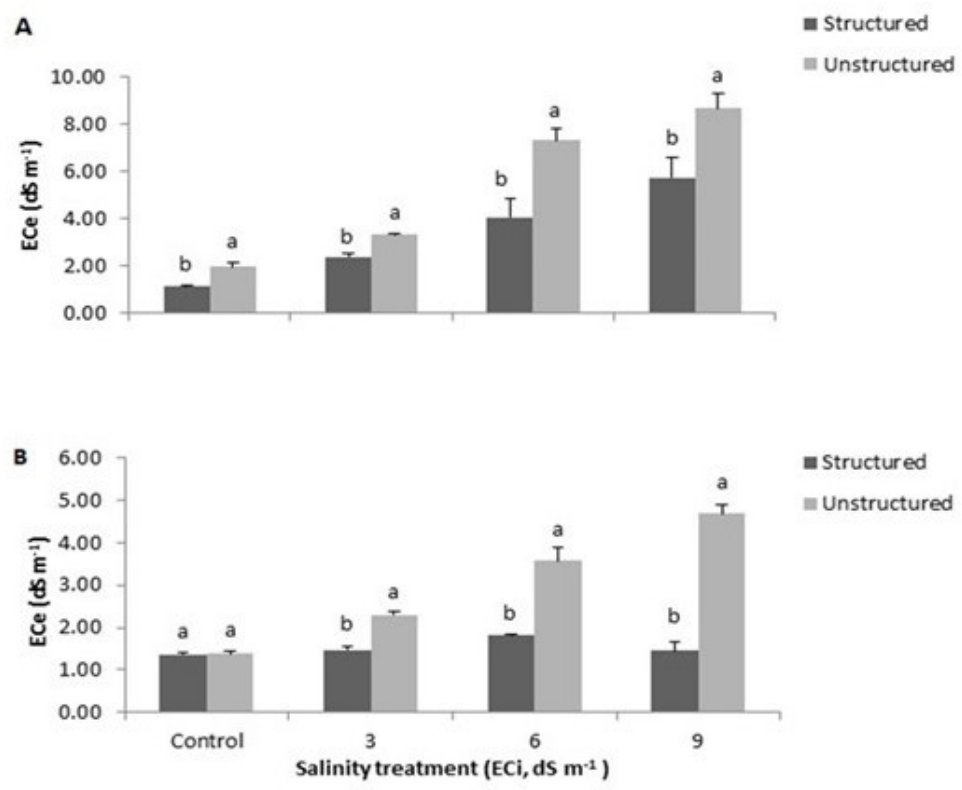

Figure 5. The ECe of the topsoil in the structured and unstructured soil at different salinity treatments (A), and the ECe of the bottom soil in the structured and unstructured soil at different salinity treatments (B)

\section{Statistical Analysis}

The data were analyzed using the analysis of variance (ANOVA) procedure (PROC ANOVA) of the SAS version 9.4 (SAS, 2018).

\section{Results}

\section{Soil Moisture Content and Electrical Conduc- tivity (EC)}

The time series of the soil $\theta v$ of both structured and unstructured soil at the two selected depths $(10 \mathrm{~cm}$ and 40 $\mathrm{cm}$ ) in unstructured soil, and (top and bottom layers) in the structured soil are presented below (Figures $4 \mathrm{~A}$ and B). The high $\theta v$ at the beginning of the experiment was because the soils were watered to allow them to settle down mechanically and also to check the irrigation system. The $\theta v$ of the top layer in the structured soil and at $10 \mathrm{~cm}$ depth in the unstructured soil was maintained within the field capacity of the soil $\left(0.20-0.25 \mathrm{~cm}^{3} \mathrm{~cm}^{-3}\right)$. The bottom layer in the structured soil showed a continuous decrease in $\theta v$ whereas almost a constant $(\theta v=$ 0.21 ) was obtained for unstructured soil at $40 \mathrm{~cm}$. This was the case during the whole experiment period.

The amount of water used to irrigate marigold plants was measured in both soil substrates using a water meter. The amount of the daily water applied to irrigate a single plant of marigold was about $0.75 \mathrm{~L}$ in the unstructured soil and $0.22 \mathrm{~L}$ in the structured soil. In other words, the structured soil required more than three times less water to maintain the targeted moisture conditions of the root zone.

The results showed that in all salinity treatments, the ECe of the topsoil was significantly higher in the unstructured soil than in the structured soil (Figure 5-A). The difference in ECe between the structured and unstructured soils was more significant at higher salinity level of irrigation water, viz. at $\mathrm{ECi}=6 \mathrm{dS} \mathrm{m}^{-1}$ (4.05 and $7.35 \mathrm{dS} \mathrm{m}^{-1}$ for structured and unstructured soil, respectively) and $9 \mathrm{dS} \mathrm{m}^{-1}$ (5.74 and $8.70 \mathrm{dS} \mathrm{m}^{-1}$ for structured and unstructured soil, respectively). The same was with the bottom soil except in control salinity level (irrigation with freshwater) where there was no significant difference between the structured and unstructured soil (Figure 5-B). Unlike the top layer of the structured soil, the bottom part showed no increase in ECe as the salinity of irrigation water increased from control $\left(1.37 \mathrm{dS} \mathrm{m}^{-1}\right)$ to $9 \mathrm{dS} \mathrm{m}^{-1}\left(1.46 \mathrm{dS} \mathrm{m}^{-1}\right)$.

\section{Vegetative Growth}

Table 1 shows a significant decrease in all marigold vegetative parameters measured in the unstructured soil as the salinity level increased. On the other hand, there was no reduction in marigold vegetative parameters measured in the structured soil as the salinity level increased. There were no significant differences between control and $3 \mathrm{dS} \mathrm{m}^{-1}$ salinity level in the vegetative growth parameters except in the root fresh weight in both structured and unstructured soil. At $6 \mathrm{dS} \mathrm{m}^{-1}$ salinity level, there was a reduction by $5.6 \%$ in shoot height, $10.1 \%$ in shoot width, $28.8 \%$ in leaf area, $30.7 \%$ in the shoot fresh weight, $24.6 \%$ in the dry shoot weight, $54.4 \%$ in the roots fresh weight, and $69.8 \%$ in the roots 


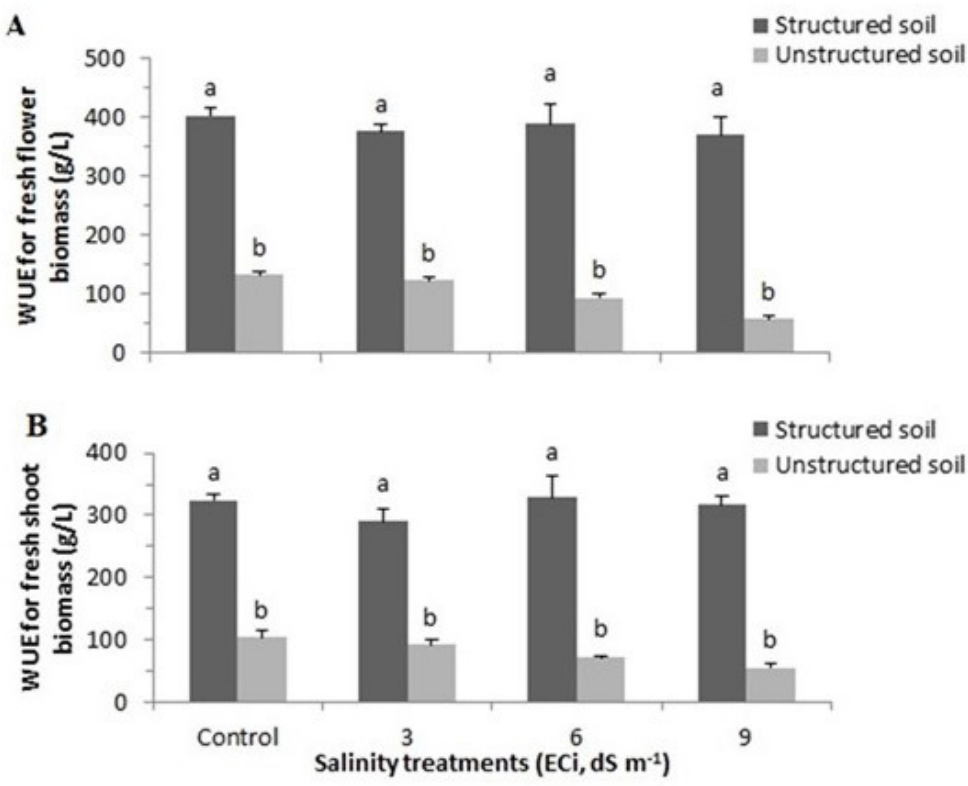

Figure 6. Water use efficiency for fresh flowers (A) and shoot biomass (B) in the structured and unstructured soil at different salinity levels

dry weight in comparison to control. The effect of $6 \mathrm{dS}$ $\mathrm{m}^{-1}$ salinity level was much less on the marigold in the structured soil where the shoot height, shoot width, leaf area, shoot fresh weight, shoot dry weight, root fresh weight, and root fresh weight decreased by $3.0 \%, 6.7 \%$, $16.9 \%, 1.5 \%, 7.4 \%, 50.8 \%$, and $63.2 \%$, respectively. At $9 \mathrm{dS}$ $\mathrm{m}^{-1}$ salinity level, all vegetative traits measured were significantly less in the unstructured soil where the shoot height, shoot width, leaf area, shoot fresh weight, shoot dry weight, root fresh weight, and root fresh weight decreased by $10.6 \%, 21.6 \%, 46.0 \%, 47.2 \%, 30.3 \%, 60.4 \%$, $75.5 \%$ respectively (Table 1 ). In contrast, there was no

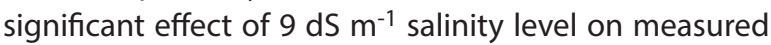
vegetative parameters (except for shoot width and leaf area) of marigold grown in the structured soil. The shoot height, shoot width, leaf area, shoot fresh weight, shoot dry weight, root fresh weight, and root fresh weight in structured soil decreased by $4.4 \%, 10.9 \%, 27.6 \%, 2.3 \%$, $4.4 \%, 21.6 \%$, and $27.4 \%$ respectively.

Table 1 also shows a comparison between the structured soil and unstructured soil, with respect to the effects of salinity stress on marigold vegetative parameters. At control and $3 \mathrm{dS} \mathrm{m}^{-1}$ salinity levels, there were no significant changes in all vegetative parameters, except in the shoot width at $3 \mathrm{dS} \mathrm{m}^{-1}$ salinity level, whereas shoot width of marigold in the unstructured soil was

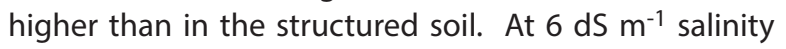
level, the shoot height and shoot width were significantly higher in the structured soil than in the unstructured

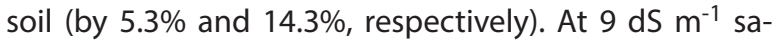
linity level, the shoot height, shoot width, and shoots fresh weight were significantly higher in the structured soil than in the unstructured soil (by $10.7 \%, 24.2 \%$, and $40.3 \%$, respectively). Overall, the structured soil resulted in significantly higher shoot height, shoot width, and leaf area.

\section{Reproductive Growth}

Table 2 depicts the effect of different salinity levels on the reproductive growth of marigold plants grown in the structured and unstructured soil. The number of flowers, their size and weight decreased as salinity level increased in the unstructured soil. However, there was no significant effect of salinity on the marigold flowering traits in the structured soil. The unstructured soil, at $\mathrm{ECi}=3 \mathrm{dS} \mathrm{m}^{-1}$, indicated a significant reduction in the size of the flowers (by $4.1 \%$ compared to control). At $\mathrm{ECi}=6 \mathrm{dS} \mathrm{m}^{-1}$, showed a reduction by $18.8 \%$ in the number of flowers, $8.7 \%$ reduction in the flower diameter, $28.9 \%$ in the flowers' fresh weight, and $10 \%$ in the flowers dry weight. In contrast, the reductions in the structured soil were only by $6.3 \%$ in the number of flowers, $2.3 \%$ reduction in the flower diameter, $3.7 \%$ in the flowers fresh weight, and $2.3 \%$ in the flowers dry weight. At $\mathrm{ECi}=9 \mathrm{dS} \mathrm{m}^{-1}$ salinity level, the number of flowers, flower diameter, flower fresh weight, and flower dry weight were decreased by $31.3 \%, 9.9 \%, 56.5 \%, 35.6 \%$, respectively in the unstructured soil and by $6.3 \%, 2.6 \%$, $8.2 \%$, and $1.3 \%$, respectively in the structured soil. Although all marigold reproductive parameters declined significantly in the unstructured soil, the reduction in the structured soil was not significant. Table 2 also compares the structured soil and unstructured soil in the effect of salinity stress on marigold reproductive param- 
Table 1. Effect of different salinity levels on vegetative growth parameters on marigold plants grown in the structured and unstructured soils

\begin{tabular}{|c|c|c|c|c|c|c|c|c|}
\hline $\begin{array}{l}\text { Sa- } \\
\text { linity } \\
\text { Level }\end{array}$ & Soil & $\begin{array}{l}\text { Shoot } \\
\text { height }\end{array}$ & $\begin{array}{l}\text { Shoot } \\
\text { width }\end{array}$ & Leaf area & $\begin{array}{c}\text { Shoot } \\
\text { fresh } \\
\text { weight }\end{array}$ & $\begin{array}{c}\text { Shoot dry } \\
\text { weight }\end{array}$ & $\begin{array}{c}\text { Root } \\
\text { fresh } \\
\text { weight }\end{array}$ & $\begin{array}{l}\text { Root dry } \\
\text { weight }\end{array}$ \\
\hline \multirow{2}{*}{ Control } & Structured & $36.67 \mathrm{Aa} \pm 0.47$ & $24.67 \mathrm{Aa} \pm 0.68$ & $19.03 \mathrm{Aa} \pm 0.64$ & $70.41 \mathrm{Aa} \pm 2.47$ & $11.95 \mathrm{Aa} \pm 0.54$ & $5.00 \mathrm{Aa} \pm 0.30$ & $2.77 \mathrm{Aa} \pm 0.55$ \\
\hline & $\begin{array}{l}\text { Unstruc- } \\
\text { tured }\end{array}$ & $35.67 A a \pm 0.62$ & $24.67 A a \pm 0.67$ & $19.25 \mathrm{Aa} \pm 0.94$ & $77.83 \mathrm{Aa} \pm 8.42$ & $11.99 \mathrm{Aa} \pm 1.22$ & $7.70 \mathrm{~A} a \pm 1.95$ & $3.51 \mathrm{Aa} \pm 0.97$ \\
\hline \multirow{2}{*}{$3 \mathrm{dS} \mathrm{m} \mathrm{m}^{-1}$} & Structured & $35.11 \mathrm{Aa} \pm 0.43$ & $23.56 \mathrm{Ab} \pm 0.65$ & $17.61 \mathrm{ABa} \pm 1.14$ & $63.15 \mathrm{~A} a \pm 4.50$ & $10.38 \mathrm{~A} a \pm 0.52$ & $2.34 \mathrm{Ba} \pm 0.27$ & $1.03 \mathrm{Aa} \pm 0.14$ \\
\hline & $\begin{array}{l}\text { Unstruc- } \\
\text { tured }\end{array}$ & $34.56 \mathrm{ABa} \pm 0.56$ & $25.22 \mathrm{Aa} \pm 0.32$ & $16.75 \mathrm{ABa} \pm 1.38$ & $68.37 \mathrm{Aa} \pm 5.56$ & $11.52 \mathrm{Aa} \pm 1.04$ & $4.00 \mathrm{Ba} \pm 0.68$ & $1.81 \mathrm{ABa} \pm 0.44$ \\
\hline \multirow{2}{*}{$6 \mathrm{dS} \mathrm{m} \mathrm{m}^{-1}$} & Structured & $35.56 \mathrm{~A} a \pm 0.46$ & $26.44 \mathrm{ABa} \pm 0.65$ & $15.81 \mathrm{BCa} \pm 0.67$ & $71.49 \mathrm{Aa} \pm 7.44$ & $11.06 \mathrm{~A} a \pm 0.73$ & $2.46 \mathrm{Bb} \pm 0.07$ & $1.02 \mathrm{Aa} \pm 0.06$ \\
\hline & $\begin{array}{l}\text { Unstruc- } \\
\text { tured }\end{array}$ & $33.67 \mathrm{Bb} \pm 0.62$ & $22.67 \mathrm{Bb} \pm 0.55$ & $13.71 \mathrm{BCa} \pm 0.91$ & $53.87 \mathrm{ABa} \pm 0.38$ & $9.04 \mathrm{ABa} \pm 0.17$ & $3.51 \mathrm{Ba} \pm 0.12$ & $1.06 \mathrm{Ba} \pm 0.09$ \\
\hline \multirow{2}{*}{$9 \mathrm{dS} \mathrm{m} \mathrm{m}^{-1}$} & Structured & $35.72 \mathrm{Aa} \pm 0.54$ & $26.11 \mathrm{Ba} \pm 0.51$ & $13.78 \mathrm{Ca} \pm 0.84$ & $68.76 \mathrm{~A} a \pm 3.17$ & $11.43 \mathrm{Aa} \pm 0.71$ & $3.92 \mathrm{ABa} \pm 0.95$ & $2.01 \mathrm{Aa} \pm 0.84$ \\
\hline & $\begin{array}{l}\text { Unstruc- } \\
\text { tured }\end{array}$ & $31.89 \mathrm{Cb} \pm 0.42$ & $19.78 \mathrm{Cb} \pm 0.91$ & $10.40 \mathrm{Ca} \pm 1.89$ & $41.06 \mathrm{Bb} \pm 5.91$ & $8.36 \mathrm{Ba} \pm 0.84$ & $3.05 \mathrm{Ba} \pm 0.46$ & $0.86 \mathrm{Ba} \pm 0.22$ \\
\hline \multicolumn{2}{|c|}{ Average of structured } & $35.77 a$ & $25.20 a$ & $16.56 a$ & $68.45 a$ & $11.21 a$ & $4.57 a$ & $1.81 \mathrm{a}$ \\
\hline \multicolumn{2}{|c|}{ Average of unstructured } & $33.95 b$ & $23.09 b$ & $15.03 b$ & $60.28 \mathrm{a}$ & $10.23 a$ & $3.43 a$ & $1.72 \mathrm{a}$ \\
\hline
\end{tabular}

Values (means \pm SE) in the same column with the same uppercase letters indicating no significant difference of the structured and unstructured soil separately at different salinity levels. Same lowercase letters in the same column indicating no significant difference between structured and unstructured soil at each salinity level at $\mathrm{p} \leq 0.05$.

eters. At control salinity level, there was no significant difference between the structured and unstructured soil in all reproductive parameters. At $\mathrm{ECi}=3 \mathrm{dS} \mathrm{m}^{-1}$, the flower diameter in the structured soil was significantly bigger than that in the unstructured soil, whereas there were no critical differences in the number of flowers and their fresh and dry weight. At $\mathrm{ECi}=6 \mathrm{dS} \mathrm{m}^{-1}$, the number of flowers produced by the marigold in the structured soil was statistically higher than that of the unstructured soil. Also, the structured soil resulted in a larger flower diameter than the unstructured soil at the same salini- ty level. At $\mathrm{ECi}=9 \mathrm{dS} \mathrm{\textrm {m } ^ { - 1 }}$, all reproductive parameters were significantly higher in the structured soil than in the unstructured soil. Taken together, the structured soil showed a significantly higher number of flowers, bigger flowers, and higher flowers' dry weight.

\section{Physiological Parameters}

The experiments showed a significant decrease in the marigold leaf chlorophyll content and chlorophyll fluorescence with increasing levels of salinity in the unstructured soil whereas no significant changes were

Table 2. Effect of different salinity levels on reproductive growth parameters on marigold plants grown in the structured and unstructured soil design

\begin{tabular}{|c|c|c|c|c|c|}
\hline Salinity Level & Soil & Shoot height & Shoot width & Leaf area & Shoot fresh weight \\
\hline \multirow{2}{*}{ Control } & Structured & $15 A a \pm 0.61$ & $6.18 \mathrm{Aa} \pm 0.06$ & $87.90 \mathrm{Aa} \pm 2.68$ & $21.94 \mathrm{Aa} \pm 1.09$ \\
\hline & Unstructured & $15 A a \pm 1.06$ & $6.06 \mathrm{Aa} \pm 0.06$ & $100.17 \mathrm{Aa} \pm 3.57$ & $20.03 \mathrm{Aa} \pm 1.26$ \\
\hline \multirow{2}{*}{$3 \mathrm{dS} \mathrm{m} \mathrm{m}^{-1}$} & Structured & $15 \mathrm{Aa} \pm 0.81$ & $6.05 \mathrm{Aa} \pm 0.05$ & $82.09 \mathrm{Aa} \pm 2.71$ & $21.27 \mathrm{~A} a \pm 0.77$ \\
\hline & Unstructured & $16 \mathrm{Aa} \pm 1.26$ & $5.80 \mathrm{Bb} \pm 0.06$ & $92.73 \mathrm{Aa} \pm 4.75$ & $22.33 \mathrm{Aa} \pm 1.16$ \\
\hline \multirow{2}{*}{$6 \mathrm{dS} \mathrm{m} \mathrm{m}^{-1}$} & Structured & $15 A a \pm 0.66$ & $6.07 \mathrm{Aa} \pm 0.06$ & $84.63 \mathrm{Aa} \pm 7.65$ & $21.43 \mathrm{Aa} \pm 2.16$ \\
\hline & Unstructured & $11 \mathrm{ABb} \pm 0.82$ & $5.53 \mathrm{Cb} \pm 0.06$ & $71.25 \mathrm{Ba} \pm 4.23$ & $17.84 \mathrm{Aa} \pm 0.82$ \\
\hline \multirow[b]{2}{*}{$9 \mathrm{dS} \mathrm{m}^{-1}$} & Structured & $16 A a \pm 0.92$ & $6.21 \mathrm{Aa} \pm 0.05$ & $80.65 A a \pm 6.57$ & $22.66 \mathrm{~A} a \pm 1.33$ \\
\hline & Unstructured & $13 \mathrm{Bb} \pm 1.38$ & $5.46 \mathrm{Cb} \pm 0.08$ & $43.56 \mathrm{Cb} \pm 5.01$ & $12.90 \mathrm{Bb} \pm 1.90$ \\
\hline \multicolumn{2}{|c|}{ Average of structured } & $15 a$ & $6.13 a$ & $83.82 \mathrm{a}$ & $21.83 a$ \\
\hline \multicolumn{2}{|c|}{ Average of unstructured } & $14 b$ & $5.71 b$ & $76.93 a$ & $18.28 b$ \\
\hline
\end{tabular}

Values (means \pm SE) in the same column with the same uppercase letters indicating no significant difference of the structured and unstructured soil separately at different salinity levels. Same lowercase letters in the same column indicating no significant difference between structured and unstructured soil at each salinity level at $p \leq 0.05$. 
observed in the marigold leaf chlorophyll content and chlorophyll fluorescence with increasing salinity level in the structured soil (Table 3). The unstructured soil showed a reduction in the chlorophyll content by $5.28 \%$, $12.17 \%$, and $18.23 \%$ at $\mathrm{ECi}=3 \mathrm{dS} \mathrm{m} \mathrm{m}^{-1}, 6 \mathrm{dS} \mathrm{m}^{-1}$, and $9 \mathrm{dS}$ $\mathrm{m}^{-1}$, respectively, compared to the control. On the other side, the structured soil showed only $2.27 \%, 1.63 \%$, and $3.04 \%$ reduction at $\mathrm{ECi}=3 \mathrm{dS} \mathrm{m} \mathrm{m}^{-1}, 6 \mathrm{dS} \mathrm{m}^{-1}$, and $9 \mathrm{dS}$ $\mathrm{m}^{-1}$, respectively, compared to the control. Chlorophyll fluorescence decreased significantly in the unstructured

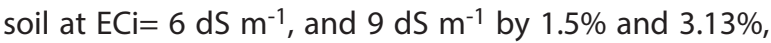
respectively, whereas the structured soil showed no significant reduction in the chlorophyll fluorescence as salinity level increased.

There were no significant differences between the structured and unstructured soils in the marigold chlorophyll content and chlorophyll fluorescence for the

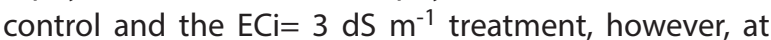

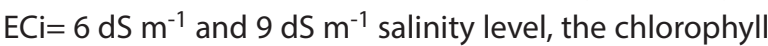
content and chlorophyll fluorescence were significantly higher in the structured soil than in the unstructured soil (Table 3). Overall, the structured soil had significantly higher chlorophyll contents and chlorophyll fluorescence.

\section{Plant Mortality}

At the end of the experiment, the number of dead plants in each treatment for both structured and unstructured soil was counted. The mortality percentages in the unstructured soil were $58.3 \%, 8.3 \%, 0 \%, 0 \%$ at $\mathrm{ECi}=9 \mathrm{dS}$

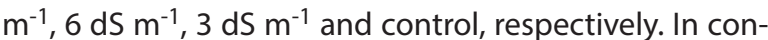
trast, the mortality percentages in the structured soil were $15 \%, 1.6 \%, 0 \%, 0 \%$ at $\mathrm{ECi}=9 \mathrm{dS} \mathrm{m}^{-1}, 6 \mathrm{dS} \mathrm{m} \mathrm{m}^{-1}, 3 \mathrm{dS}$ $\mathrm{m}^{-1}$ and control, respectively. The mortality of marigold plants in the structured soil was less by five to four times compared to the unstructured soil when irrigated with
$\mathrm{ECi}=6 \mathrm{dS} \mathrm{m}^{-1}$ and $\mathrm{ECi}=9 \mathrm{dS} \mathrm{\textrm {m } ^ { - 1 }}$, respectively.

\section{Water Use Efficiency}

The WUE, which was based on the marigold fresh flower and shoot biomass to the daily irrigation water applied, is presented in Figure 6. WUE for shoot biomass varied from $328.85 \mathrm{~g} / \mathrm{L}$ (in the structured soil at $\mathrm{ECi}=6 \mathrm{dS}$ $\mathrm{m}^{-1}$ ) to $54.79 \mathrm{~g} / \mathrm{L}$ (in the unstructured soil at $\mathrm{ECi}=9 \mathrm{dS}$ $\mathrm{m}^{-1}$ ). The WUE for flowers varied from $404.34 \mathrm{~g} / \mathrm{L}$ (in the structured soil at control salinity level) to $58.12 \mathrm{~g} / \mathrm{L}$ (in the unstructured soil at $\mathrm{ECi}=9 \mathrm{dS} \mathrm{m}^{-1}$ ). There was a decreasing trend in WUE for both shoots and flowers biomass as the salinity level increased. This decrease in WUE was more obvious in the unstructured soil than in the structured soil. WUE for flower biomass in the unstructured soil at control was $66.9 \%$ less than in the structured soil, and the differences increased with salinity. The difference was $67.2 \%, 75.6 \%$, and $84.3 \%$ at $\mathrm{ECi}=$ $3 \mathrm{dS} \mathrm{m}^{-1}, 6 \mathrm{dS} \mathrm{m}^{-1}$, and $9 \mathrm{dS} \mathrm{m}^{-1}$, respectively. Also, the WUE for shoot biomass in the unstructured soil at control was $67.9 \%$ less than in the structured soil, and the differences increased with the salinity. The difference was $68.6 \%, 78.1 \%$, and $82.7 \%$ at $\mathrm{ECi}=3 \mathrm{dS} \mathrm{m} \mathrm{m}^{-1}, 6 \mathrm{dS} \mathrm{m}^{-1}$, and $9 \mathrm{dS} \mathrm{m}^{-1}$, respectively.

\section{Discussion}

\section{Structured Soil on Water Saving and Salts Ac- cumulation}

Smartly structured soil substrate designed in this study showed a high capacity to save water and reduce salts accumulation compared to unstructured soil. The amount of water used to irrigate marigold plants in the unstructured soil was more than three times, as compared with that in the structured soil. The key reason for this huge

Table 3. Effect of different salinity levels on physiological parameters on marigold plants grown under structured and unstructured soil configurations

$\begin{array}{llll}\text { Salinity Level }(\mathrm{ECi}) & \text { Soil } & \begin{array}{l}\text { Chlorophyll content } \\ \text { (SPAD readings) }\end{array} & \begin{array}{l}\text { Chlorophyll fluorescence } \\ \text { (Fv/Fm) }\end{array} \\ & \text { Structured } & 63.84 \mathrm{Aa} \pm 0.87 & 0.65 \mathrm{Aa} \pm 0.00 \\ \text { Control } & \text { Unstructured } & 63.69 \mathrm{Aa} \pm 0.65 & 0.64 \mathrm{ABa} \pm 0.01 \\ & \text { Structured } & 62.20 \mathrm{Aa} \pm 0.80 & 0.65 \mathrm{Aa} \pm 0.00 \\ 3 \mathrm{dS} \mathrm{m}^{-1} & \text { Unstructured } & 60.33 \mathrm{Ba} \pm 0.94 & 0.66 \mathrm{Aa} \pm 0.01 \\ & \text { Structured } & 63.23 \mathrm{Aa} \pm 0.59 & 0.65 \mathrm{Aa} \pm 0.00 \\ 6 \mathrm{dS} \mathrm{m}^{-1} & \text { Unstructured } & 55.94 \mathrm{Cb} \pm 0.95 & 0.63 \mathrm{BCb} \pm 0.01 \\ & \text { Structured } & 61.90 \mathrm{Aa} \pm 0.74 & 0.64 \mathrm{Aa} \pm 0.00 \\ 9 \mathrm{dS} \mathrm{m}^{-1} & \text { Unstructured } & 52.08 \mathrm{Db} \pm 1.62 & 0.62 \mathrm{Cb} \pm 0.01 \\ \text { Average of structured } & & 62.79 \mathrm{a} & 0.65 \mathrm{a} \\ \text { Average of unstructured } & & 58.01 \mathrm{~b} & 0.64 \mathrm{~b}\end{array}$

Values (means $\pm \mathrm{SE}$ ) in the same column with the same uppercase letters indicating no significant difference of the structured and unstructured soil separately at different salinity levels. Same lowercase letters in the same column indicating no significant difference between structured and unstructured soil at each salinity level at $p \leq 0.05$. 
water saving is the presence of the unique 3-D CB in our structured soil. Our smart composite prevents or retards moisture movement from the pores of the silt blocks to sand. The engineered soil architecture reduces both the upward moisture movement during evaporation and downwards water seepage during infiltration (Al-Ismaily et al., 2015; Al-Saqri et al., 2016). Therefore, structuring the soil allows the root zone to hold more "productive" water than in homogeneous soils and to prevent it from evaporative-percolation losses. Thus, water is depleted at a slow rate through favourable transpiration rather than evaporation and deep percolation (Al-Maktoumi et al., 2014). Water resources in the arid and semi-arid zones of the Arabia are very scarce. Thus, saving irrigation water is of paramount importance for agriculture, urban landscaping and - in general - for national economies of MENA countries.

In terms of salt accumulation, the ECe of the top and bottom structured soil was significantly less than the $E C e$ of the unstructured soil at all salinity levels of irrigation water (Figures $5 \mathrm{~A}$ and $5 \mathrm{~B}$ ). The difference in $\mathrm{ECe}$ between the structured and unstructured soils was more significant at higher salinity levels of irrigation water,

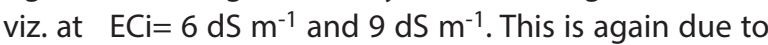
higher evaporation rates in the unstructured soil compared to the structured soil (Al-Maktoumi et al., 2014). During evaporation, salts move with water to accumulate at the soil surface and shallow sub-surface (Goosen and Shayya,1999). Therefore, due to the higher water evaporation (and high norms of irrigation with saline water in the unstructured soil), there was much more salt accumulation in the unstructured soil.

\section{Effect of Salinity on the Vegetative and Repro- ductive Growth and Physiology of Marigold Grown in the Structured and Unstructured Soils}

Increasing water salinity level in this study was much correlated with the reduction in vegetative, reproductive and physiological parameters of marigold grown in the unstructured soil compared to structured soil (Tables 1-3). Plant parameters were significantly better in structured soils compared to unstructured soils including shoot height, canopy width, leaf area, number of flowers, flower diameters, and floral dry weight (Tables 1 and 2), and plant physiological parameters (Table 3). This may have been attributed to the lower salts accumulated in the structured soil than in the unstructured soil (Figures 5A and 5B). Marigold vegetative characteristics such as shoot height, root length, no of leaves, fresh and dry biomass of marigold exhibited reduction under high concentration of $\mathrm{NaCl}(150$, and $200 \mathrm{mM} \mathrm{NaCl})$ (Sayyed et al., 2014). Furthermore, Chrysargyris et al., 2018 found that salinity of $100 \mathrm{mM} \mathrm{NaCl}$ decreased marigold flower weight, plant fresh and dry biomass, plant height and had a negative effect on physiological processes such as stomatal closure and chlorophylls content decrease.
In the present study, structured soil was so effective in mitigating salinity stress of marigold plants. Our results are in agreement with Cude et al., (2018) who reported that a standard (layered) CB led to reductions or smaller increases in salinity than in treatments without a CB. Also, Ityel et al., (2012) showed that the bell pepper plants grown above a CB yielded $24 \%$ higher biomass than control plants, particularly, under saline condition. Furthermore, Rooney et al., (1998) reported that placing a CB under the root zone was effective to prevent salinization from underlying sources by stopping the capillary rise.

\section{Plant Mortality}

The mortality percentage of the marigold in the unstructured soil was $58.3 \%$ at $\mathrm{ECi}=9 \mathrm{dS} \mathrm{m}^{-1}$ and $8.3 \%$ at $\mathrm{ECi}=6$ $\mathrm{dS} \mathrm{m}^{-1}$ whereas in the structured soil it was only $15 \%$ at $\mathrm{ECi}=9 \mathrm{dS} \mathrm{m}^{-1}$ and $1.7 \%$ at $\mathrm{ECi}=6 \mathrm{dS} \mathrm{m}^{-1}$. The higher mortality in the marigold grown in the unstructured soil is because of higher concentrations of salts accumulated in the unstructured soil than in the structured soil. High soluble salts in the soil lead to osmotic stress, specific ion toxicity and ionic imbalances (Munns, 1993) and, as a result, plants grown under these intolerable saline conditions die (Rout and Shaw, 2001). Ozturk et al. (2004) showed that all seedlings of Melissa officinalis died at $6 \mathrm{dS} / \mathrm{m}$. Also, increasing soil salinity with $\mathrm{NaCl}$ salt up to $3000 \mathrm{ppm}$, corresponding to $5.7 \mathrm{dS} \mathrm{m}^{-1}$, resulted in the complete death of sage plants (Hendawy and Khalid, 2005). Thus, our 3-D CB structured soil composites reduce salinity stress on the plants.

\section{Water Use Efficiency}

Structured soil showed a great impact on improving WUE, viz. about $66.9 \%$ improvement in the WUE for flower biomass and $67.9 \%$ for shoot biomass at control salinity level comparing with unstructured soil. The difference in WUE between the structured soil and unstructured soil was greater at higher salinity levels. There was $67.2 \%, 75.6 \%$, and $84.3 \%$ improvement in the WUE at $\mathrm{ECi}=3 \mathrm{dS} \mathrm{m}^{-1}, 6 \mathrm{dS} \mathrm{m}^{-1}$, and $9 \mathrm{dS} \mathrm{m}^{-1}$, respectively for flower biomass and $68.6 \%, 78.1 \%$, and $82.7 \%$ at $\mathrm{ECi}=3$ $\mathrm{dS} \mathrm{m} \mathrm{m}^{-1}, 6 \mathrm{dS} \mathrm{m}^{-1}$, and $9 \mathrm{dS} \mathrm{m}^{-1}$ salinity level, respectively for shoot biomass. The higher WUE for both flowers and shoot biomass in the structured soil than in the unstructured soil was due to less amount of water required to irrigate the marigold plants grown in the structured soil compared to the unstructured soil. Soil with even $1-D C B$ store more water than those without CB (Bruch, 1993; Zornberg et al., 2010; Huang et al., 2011). The CB can improve WUE by minimizing water loss and/or increasing the crop yield. Several studies have shown the capability of the CB in improving WUE. An experiment conducted in greenhouses during cultivation of a horticultural crop by Ityel et al. (2012) found that the installation of a CB increased $60 \%$ the soil water content and $25 \%$ the fruit yield for green peppers, and increased the 
matric head by $80 \%$ and the biomass yield by $36 \%$ for lettuce. A numerical study by Wongkaew et al. (2018) demonstrated the role of a $C B$ in improving the root zone conditions and maximizing WUE. Moreover, Sadegh-Zadeh et al. (2009) indicated that CB can increase the water holding capacity and soil water content in layered soils.

\section{Conclusion \& Recommendations}

Marigolds were grown in two soil configurations: structured and unstructured soils. In each soil treatment, marigolds were subjected to four salinity levels of irrigation water. The results showed the ability of the structured soil, through its silty soil sandwiched by a sand-filled maze of horizontal and vertical fingers, to conserve the soil moisture more than three times, as compared with the unstructured soil. The WUE for both marigold flower and shoot biomass were much higher in the structured soil than in the unstructured soil. The WUE in the unstructured soil was $66.9 \%$ less than in the structured soil for flowers biomass, and $67.9 \%$ less for shoot biomass at control salinity level and the differences increased with salinity. Also, the structured soil significantly reduced salt accumulation in the roots zone where the ECe of the structured soil was significantly higher than the ECe of the unstructured soil.

Moreover, marigold in the structured soil substrate showed better growth and flower production than the marigold in the unstructured soil, especially, at higher salinity levels. The physiological, vegetative and reproductive parameters of marigold in the unstructured soil significantly decreased with salinity of irrigation water. There were no significant changes due to irrigation with saline water in most physiological, vegetative and reproductive parameters of marigold in the structured soil compared to unstructured soil. Therefore, our study explored and substantiated a novel method in mitigating salinity problem, water-saving, and improving roots zone conditions and thereby improving crop production and WUE especially under the harsh conditions of desertic farming. Further studies are needed to evaluate this smart-design soil with different plants including fruits, vegetables and ornamental plants of different root systems and growth patterns and under different irrigation systems.

\section{Acknowledgment}

The authors acknowledge the financial support from Sultan Qaboos University (SQU) and the Sultan Qaboos Higher Center for Culture and Science - Diwan of Royal Court and the Research Council of Oman (TRC) [RC/AGR/ SWAE/17/01]. The technical help by the Agricultural Experiment Station (AES) staff is highly appreciated.

\section{References}

Abrol IP, Yadav JSP, Massoud FI. (1988). Salt-affected soils and their management. Food and Agriculture Organization. Soils Bulletin 39, Rome, Italy.

Al-Ismaily S, Al-Maktoumi A, Kacimov A, Al-Saqri S, Al-Busaidi H. (2013). The impact of a recharge dam on the hydropedology of arid zone soils in Oman: anthropogenic formation factor. Journal of Hydrologic Engineering.10.1061/(ASCE) HE. 1943-5584.0000886, 04014053

Al-Ismaily S, Al-Maktoumi A, Kacimov A, Al-Saqri S, Al-Busaidi H, Al-Haddabi M. (2013). Morphed block-crack preferential sedimentation in a reservoir bed: a smart design and evolution in nature.

Al-Maktoumi A, Al-Ismaily S, Kacimov A, Al-Busaidi $\mathrm{H}$, Al-Saqri S, Al-Hadabi M. 2014. Soil substrate as a cascade of capillary barriers for conserving water in a desert environment: lessons learned from arid nature. Journal of Arid Land 6(6): 690-703

Al-Mazroui, M, Al-Yahyai, R, Al-Ismaily S, Kacimov A. (2019). The effects of layered artificial substrates on marigold vegetative and reproductive growth. Acta Horticulturae (in press).

Al-Mulla Y. (2010). Salinity mapping in Oman using remote sensing tools: status and trends. Published in the Monograph on Management of Salt-Affected Soils and Water for Sustainable Agriculture (Mushtaque A, Al-Rawahi SA, Hussain N (eds). Sultan Qaboos University, Oman, pp 17-24

Al-Rawahy SA, Ahmed M, Hussain N. (2010). Management of salt-affected soils and water for sustainable agriculture: the project. Published in the Monograph on Management of Salt-Affected Soils and Water for Sustainable Agriculture (Mushtaque A, Al-Rawahi SA, Hussain N (eds). Sultan Qaboos University, Oman, pp $1-8$

Al-Saqri S, Al-Maktoumi A, Al-Ismaily S, Kacimov A, Al-Busaidi H. (2016). Hydropedology and soil evolution in explaining the hydrological properties of recharge dams in arid zone environments. Arabian Journal of Geosciences 9(1):1-12.

Ashraf MY, Khan MA, Maqvi SSM. (1991). Effect of salinity on seedling growth and solutes accumulation in two wheat genotypes. Rachis 10: 30-31.

Bouyoucos GJ. (1962). Hydrometer method improved for making particle size analyses of soils. Agronomy Journal, 54: 464-465.

Bruch PG. (1993). A laboratory study of evaporative fluxes in homogeneous and layered soils. MSc Thesis, Dept of Civil Eng, University of Saskatchewan, Saskatoon, Canada

Cude SM, Ankeny MD, Norton JB, Kelleners TJ, Strom CF. (2018). Capillary barriers improve reclamation in 
drastically disturbed semiarid shrubland. Arid Land Research and Management 32(3): 259-276.

Ghassemi F, Jakeman AJ, Nix HA. (1995). Salinisation of land and water resources: human causes, extent, management and case studies. University of New South Wales press, Sydney

Goosen MFA, Shayya WH. (1999). Water management, purification and conservation in arid climates. In Goosen MFA, Shayya WH (eds) Water management, vol I. Technomic Publishing Co., Lancaster, pp 1-6

Hendawy SF, Khalid KA. (2005). Response of sage (Salvia officinalis L.) plants to zinc application under different salinity levels. Journal of Applied Sciences Research 1: 147-155.

Huang M, Lee Barbour S, Elshorbagy A, Zettl JD, Si BC. (2011). Infiltration and drainage processes in multi-layered coarse soils. Canadian Journal of Soil Science, 91: 169-183.

Ityel E, Lazarovitch N, Silberbush M, Ben-Gal A. (2012). An artificial capillary barrier to improve root-zone conditions for horticultural crops: Response of pepper plants to matric head and irrigation water salinity. Agricultural Water Management 105: 13-20

Ityel E, Lazarovitch N, Silberbush M, Ben-Gal A. (2010). An artificial capillary barrier to improve root zone conditions for horticultural crops: physical effects on water content. Irrigation Science 29(2): 171-180.

Jamil A, Riaz S, Ashraf M, Foolad M. (2011). Gene expression profiling of plants under salt stress. Critical Reviews in Plant Sciences 30: 435-458.

Kacimov A, Al-Maktoumi A, Al-Ismaily S, Al-Busaidi H. (2017). Moisture and temperature in a proppant-enveloped silt block of a recharge dam reservoir: Laboratory experiment and 1-D mathematical modelling. Journal of Agricultural and Marine Sciences 22(1): 8-17.

Khan AH, Ashraf MY, Naqvi SSM, Khanzada B, Ali M. 1995. Growth, ion and solute contents of sorghum grown under $\mathrm{NaCl}$ and $\mathrm{Na} 2 \mathrm{SO} 4$ salinity stress. Acta Physiologiae Plantarum 17: 261-268.

Kim HJ, Fonseca JM, Choi JH, Kubota C, Kwon DY. (2008). Salt in irrigation water affects the nutritional and visual properties of romaine lettuce (Lactuca sativa L.). Journal of Agricultural and Food Chemistry 56: 3772-3776.

Machado RMA, Serralheiro RP. (2017). Soil salinity: effect on vegetable crop growth. Management practices to prevent and mitigate soil salinization. Horticulturae 3: 30 .
Munns R. (1993). Physiological processes limiting plant growth in saline soils: some dogmas and hypotheses. Plant, Cell and Environment 16: 15-24.

Nemoto Y, Sasakuma T. (2002). Differential stress responses of early salt-stress responding genes in common wheat. Phytochemistry 61: 129-133.

Ozturk A, Unlukara A, Ipek A, Gurbuz B. (2004). Effect of salt stress and water deficit on plant growth and essential oil content of lemon balm (Melissa officinalis L.). Pakistan Journal of Botany 36: 787-792.

Qadir M, Ghafoor A, Murtaza G. (2000). Amelioration strategies for saline soils: a review. Land Degradation Development 11:501-521.

Rhoades JD. (1996). Salinity: Electrical conductivity and total dissolved solids. Methods Soil Anal Part 3 Chemical Methods 417-435

Rooney DJ, Brown KW, Thomas JC. (1998). The effectiveness of capillary barriers to hydraulically isolate salt contaminated soils. Water, Air, and Soil Pollution $104: 1573-2932$.

Rout NP, Shaw BP. (2001). Salt tolerance in aquatic macrophytes: possible involvement of the antioxidative enzymes. Plant Science 160(3): 415-423.

Sadegh-Zadeh F, Seh-Bardan BJ, Samsuri AW, Mohammadi A, Chorom M, Yazdani GA. (2009). Saline soil reclamation by means of layered mulch. Arid Land Research and Management 23(2): 127-136.

SAS. (2018). SAS Institute Inc/STAT (Version 9.4). Cary, NC: SAS Institute Inc.

Sinclair TR, Tanner CB, Bennett JM. (1984). Water-use efficiency in crop production. BioScience 34(1): 3640.

Soil Survey Staff. (2014). Soil Survey Field and Laboratory Methods Manual.Soil Survey Investigations Report No. 51 Version 2. USDA-NRCS, Lincoln, NE

Van Genuchten MT van, Leij FJ, Yates SR. (1991). The RETC code for quantifying the hydraulic functions of unsaturated soils. Technical Report EPA/600/291/065, US Environmental Protection Agency

Wongkaew A, Saito H, Fujimaki H, Šimůnek J. (2018). Numerical analysis of soil water dynamics in a soil column with an artificial capillary barrier growing leaf vegetables. Soil Use and Management 34(2): 206-215.

Zornberg J, McCartney J, Bouazza A. (2010). Geosynthetic capillary barriers: current state of knowledge. Geosynthetics International 17(5): 273-300. 